\title{
The effect of non-genetic factors on the early body weights of Tunisian local goats
}

\author{
Ouni Mabrouk ${ }^{1,3}$, Najari Sghaier ${ }^{1}$, Roberto Germano Costa ${ }^{2}$, Gaddour Amor ${ }^{1}$, Ben Ammar \\ Elgaaied Amel ${ }^{3}$, Juan Vicente Delgado 4
}

\footnotetext{
${ }^{1}$ Laboratoire d'Elevage et de la Faune Sauvage des Régions Arides et Désertiques. Institut des Régions Arides. Médenine, Tunisie. 2 Universidade Federal da Paraíba, Bananeiras, Paraíba, Brazil.

${ }^{3}$ Laboratoire de Génétique, Immunologie et Pathologies humaines: Faculté des Sciences de Tunis.

${ }^{4}$ Departamento de Genética, Edificio Gregor Mendel, Campus de Rabanales, Universidad de Cordoba, 14071-Cordoba, Spain.
}

ABSTRACT - It was evaluated in this study the environmental effects on body weights of goat kids from birth to 150 days of age of Tunisian local goat population, on the basis of 1,656 records obtained from the Arid Areas Institute of Médenine, Tunisia, during 2001-2005. Except for birth weight, individual records were adjusted for standard ages (30, 60, 90, 120 and 150 days) using either extrapolation or interpolation on field data. Data were analyzed by GLM procedure and SNK $(\alpha=0.05)$ means comparison test. The kidding year (2001-2005), kidding month (December, January, February, and March), birth type (single and twins), sex (male and female), coat colour of kid and age of dam (2-10 years) were definied as non-genetic factors. Results showed that mean values and standard deviation (SD) of body weight at birth (0), 30, 60, 90, 120 and 150 days of age were $2.57 \pm 0.52 \mathrm{~kg}, 4.06 \pm 1.16 \mathrm{~kg}, 6.99 \pm 1.87 \mathrm{~kg}, 8.90 \pm 2.46 \mathrm{~kg}, 11.48 \pm 3.35 \mathrm{~kg}$ and $13.53 \pm 4.80 \mathrm{~kg}$ for male and $2.29 \pm 0.44 \mathrm{~kg}, 4.76 \pm 1.13 \mathrm{~kg}, 3.09 \pm 1.33 \mathrm{~kg}, 8.08 \pm 2.02 \mathrm{~kg}, 10.24 \pm 2.36 \mathrm{~kg}$ and $12.15 \pm 6.54 \mathrm{~kg}$ for female. The kidding year, birth type and sex had effect on body weights of Tunisian local kids at all ages. The single and male was always heavier than the twins and the females. The birth month had effect on all body weights except for weight at 30 days of age. The age of dam had effect on body weights from 60 to 150 days of age. However, the coat color had no significant effect on all body weights. Environmental effects estimated in this study are important and need to be taken into account for Tunisian local goat management and breeding improvement under harsh conditions.

Key Words: arid zone, birth type, environmental, growth, kids

\section{Efeito de fatores não-genéticos sobre o peso corporal inicial de caprinos na Tunísia}

RESUMO - Neste estudo, foram avaliados os efeitos ambientais sobre o peso corporal do nascimento aos 150 dias de idade de caprinos na Tunísia com base em 1.656 registros obtidos em caprinos localizados em zonas áridas do Instituto de Medenine-Tunísia, durante 2001-2005. Exceto para peso ao nascimento, registros individuais foram ajustados à idadepadrão (30, 60, 90, 120 e 150 dias) usando interpolação ou extrapolação sobre os dados de campo. Os dados foram analisados pelo procedimento GLM e as médias comparadas pelo teste SNK ( $\alpha=0,05)$. Ano de nascimento (2001-2005), mês de nascimento (janeiro, fevereiro, março e dezembro), tipo de parto (simples e duplos), sexo (macho e fêmea), cor do pelame e idade da mãe (2 a 10 anos) foram definidos como fatores não-genéticos. Os valores médios e os desvios-padrão de peso corporal ao nascimento e aos 30,60, 90, 120 e 150 dias de idade foram 2,57 $\pm 0,52 \mathrm{~kg}, 4,06 \pm 1,16 \mathrm{~kg}$, $6,99 \pm 1,87 \mathrm{~kg}, 8,90 \pm 2,46 \mathrm{~kg}, 11,48 \pm 3,35 \mathrm{~kg}$ e $13,53 \pm 4,80 \mathrm{~kg}$ para os machos e 2,29 \pm 0,44 kg, 4,76 $\pm 1,13 \mathrm{~kg}$ $3,09 \pm 1,33 \mathrm{~kg}, 8,08 \pm 2,02 \mathrm{~kg}, 10,24 \pm 2,36 \mathrm{~kg}$ e $12,15 \pm 6,54 \mathrm{~kg}$ para as fêmeas. O ano de nascimento, tipo de nascimento e sexo tiveram efeito no peso dos cabritos em todas as idades. Os cabritos machos e de partos simples foram sempre mais pesados que os de partos múltiplos e que as fêmeas. O mês de nascimento teve efeito nos pesos corporais em todas as idades, exceto aos 30 dias de idade. A idade da mãe teve efeito no peso corporal aos 60 e aos 150 dias de idade. No entanto, a cor do pelame não teve qualquer efeito em nenhum dos pesos. Os efeitos ambientais estimados neste estudo são importantes e devem ser considerados na gestão e no melhoramento genético de caprinos locais em condições severas da Tunísia.

Palavras-chave: ambiente, cabritos, crescimento, tipo de nascimento, zona árida 


\section{Introduction}

Goat pastoral breeding plays an important role in increasing employment, capital income storage and improving household nutrition in the southern arid zone of Tunisia through the valorisation of the pastoral resources under hard conditions (Ouni et al., 2007). Raising small ruminants does not require large management skill and it can be easily managed by families (Husain et al., 1996; Oliveira et al., 2010). Local goat pastoral breeding mode remains a particular importance in the Tunisian arid region (Ouled Belgacem, 2006), where more than $60 \%$ of the national goat herd estimated in 1,500,000 goats (DGPDA, 2005) is raised. Meat is the main product of the pastoral breeding mode of the indigenous goats (Kosgey et al., 2006).

Regarding the birth season, the market requires ranges on the age of the kids between 4 to 8 months, which usually coincides with the summer period. Consequently, the improvement of the production of meat of kids during this early age has an important economic impact on the income of the ambulant herds (Gaddour et al., 2007). Under pastoral harsh conditions with restricted and irregular resources, goat productivity is highly influenced by non-genetic factors because of the extensive grazing management (Mahjoub et al., 2005). In fact, arid zones are essentially defined by their food restrictions, climatic stress and conditions of instability (Ouni et al., 2008b).

The genome of the kid acquired at fecundation defines the target mature size and the potential growing (WalkdenBrown et al., 1994) whereas environmental factors affect the genotype expression and modify the resulting phenotype (Knnan et al., 2006). While the genotype remains invariable, non genetic factors vary during the productive life of the animal illustrating natural and technical fluctuations (Genandoy et al., 2002). Like other animal phenotypes, growth curve parameters and shape are changed by all factors affecting the growth rather than the individual genetic potential differences (Bocquier et al., 1998; Oltenacu, 1999; Najari et al., 2007a).

Under arid conditions, in addition to the non-genetic factors, classic effects, a specific qualitative action upon growth of kids was verified (Najari et al., 2002). Stresses and restrictions can avoid the genetic potential expression even for rustic populations. By establishing a breeding plan or estimating genetic parameters, statistical model should correctly take into account all environmental effects and interactions (De Lange et al., 1998). The main objective of this study was to research the effects of environmental factors upon the early growth of Tunisian local goat under the Maghrebian goat management systems.

\section{Material and Methods}

All studied animals belong to the goat experimental

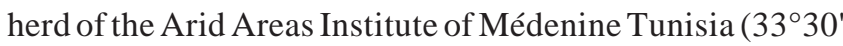
$\mathrm{N}$ and $10^{\circ} 40^{\prime} \mathrm{E}$ ), which is located in southeastern Tunisia, between the mountains of Matmata and the Mediterranean Sea. This region is characterized by an arid continental Mediterranean climate, with irregular precipitations with an average annual rainfall of about $200 \mathrm{~mm}$. Summer is normally the hottest and driest season with a maximum temperature of $47^{\circ} \mathrm{C}$ (Ouni et al., 2007).

The Tunisian local goat population is very polymorphic (Najari, 2005), but it is generally characterised by its small body size with average height of $76 \mathrm{~cm}$ for the male and 60 $\mathrm{cm}$ for the female (Ouni et al., 2008a). This local goat breed is famous for its walking ability, resistance to hydric restrictions and high temperature stresses and good productivity in harsh conditions. The native goat is hairy and basically black, with the fertility rate of about $87 \%$ and prolificacy rate of $110 \%-130 \%$ (Najari et al., 2007b). The kidding season is concentrated in the period of OctoberFebruary, with a concentration in November-December, but with a polyestric capacity (Najari, 2005).

A total of 1,656 records were collected from 276 local kids born between 2002 to 2005 through a periodical weighing program from November to August. Individual data file contains the following records: identification of doe and kid, coat colour, birth type, birth day, sex, birth weight, body weights and weighing dates of each kid and the age of the dam at kidding. Body weights were recorded every two weeks with a precision of $0.05 \mathrm{~kg}$ using the regular method, and then adjusted to the body weights at 30, 60, 90, 120 and 150 days of age by extrapolation as described by Ouni (2006). The year of birth (2002-2005), kidding month (January, February, March and December), birth type (single and twins), sex, coat colour of kid and age of dam (2-10 years, both included) were analysed as fixed effects.

The data were analyzed using the SAS package (SAS, 1999). The direct effects of the non-genetic factors on the body weights at different ages were obtained by an ANOVA analysis using the PROC GLM according to the following model:

Yijklmno $=\mu+\mathrm{Bi}+\mathrm{Mj}+\mathrm{Ak}+\mathrm{Sl}+\mathrm{Tm}+\mathrm{Pn}+\varepsilon \mathrm{ijklmn}$ where Yijklmno is a single measurement of body weight of the individual; $\mu$ = overall mean; $\mathrm{Bi}=$ effect of birth year $\mathrm{i} ; \mathrm{Mj}=$ effect of kidding month $\mathrm{j}$; Ak=effect of the age of the dam k; Sl=effect of sex l; Tm = effect of birth type m; Pn =effect of the coat color pattern n; cijklmn = random error assumed to be normally and independently distributed. The meaning of SNK is that the comparison 
test ( $\alpha=0.05$ ) was performed to diagnose the inter-classes homogeneity for each non-genetic factor. In cases where the effect of the factor was significant a pos hoc mean homogeneity Duncan test was implemented to define the concrete responsibilities of the differences in the levels of the factor.

Double interactions among factors resulted no significant and then removed from the model to simplify the calculation process. Data set did not permit to obtain solutions to triple interactions.

\section{Results and Discussion}

The body weights at different ages varied significantly with regarded to kidding year, birth type, and sex. The birth month showed effect $(\mathrm{P}<0.01)$ on all the body weights except at 30 days of age. The age of the dam also showed effects $(\mathrm{P}<0.01)$ on the body weights from 60 to 150 days of age. However, the effect of the coat color was not significant for all body weights.

These results were in agreement with the local literature reports (Gebrelul et al., 1994; Gbangboche et al., 2006). Djemali et al. (1994) mentioned that sex, birth type, age of dam, kidding year and ram effects are important sources of variation for growth traits from birth to 3 months of age. Likewise, all studies performed on goat growth data concluded that phenotypes of the kids were significantly influenced by environmental factors, especially under arid harsh conditions. In fact, the hard and irregular climate largely varied the stress and restriction effects, which modulate the growing behaviour of animals (Najari, 2005). Portolano et al. (2002) concluded that the non-genetic factors were found to be significant for body weights at birth, 15 and 60 days of age. For body weights at 30 and 45 days of age, only the year and birth type effects were found to be significant.

The mean value of body weight at 150 days of age is almost as five times as much the body weight at birth (Table 1). According to Ouni (2006) the animals from this population have approximately $83 \%$ stature of an adult at this age. Indeed, our findings demonstrated that only $4 / 5$ of the adult body mass is reached at 5 months age. Morand-
Fehr (1981) announced that birth weight of a kid primarily depends on the body conformation and size of their parents. In fact, the body weight of the dam and the birth weight of their kids have positive correlation coefficient irrespective of the litter sizes (Morand-Fehr, 1981).

The growth of the kids stagnates in the summer season, which coincides with the age of 4 or 5 months according to the kidding season (Najari, 2005). This aspect can be considered as an adaptative strategy to the different management modes and growth conditions of pastoral breeding under arid conditions (Le Gal Planchenault, 1993).

The most important period of growth seems to be the first five months of life, when the growth rate of the kids produces the main part of the adult meat mass (Ouni, 2006; Najari et al., 2007a). In addition, it has to be emphasized that the considerable diversity found in all the reference ages tested in the population as demonstrated in the ANOVA results is explained by the intra group large variability characteristic of populations raised in large irregular zones (Pariacote, 2003). Effects of year and month of birth result from the variability of climatic conditions, which influence the forage availability to dams that in turn influence their milk production (Najari et al., 2007a).

The kidding year showed a high effect $(\mathrm{P}<0.01)$ on the body weights of the kids from birth to 150 days of age. Ndlovu \& Simela (1996) obtained similar results for goats from Zimbabwe. Najari et al. (2007b) also mentioned an influence $(\mathrm{P}<0.05)$ of the kidding year because of annual variations, which may be due to the variant productivity of the range lands.

The scarcity and irregularity of precipitations, as hot and cold oscillations, are the main natural factors affecting the growth of the animals, especially in young kids. Year oscillations characterize the arid environment, affecting the feed availability which is the main reason for the year effect on variability (Ouni et al., 2007; Najari et al., 2007a). The importance of the year effect on the growth performances under difficult conditions has been highlighted by other reports (Alexandre et al., 1997; Zhang et al., 2006). Ndlovu \& Simela (1996) reported that the kids born in the hot dry season were heavier $(\mathrm{P}<0.05)$ around the ages of 60 and 90

Table 1 - Means of body weights at birth, 30, 60, 90, 120 and 150 days of age for Tunisian local kids from the kidding year

\begin{tabular}{|c|c|c|c|c|c|c|}
\hline \multirow{2}{*}{ year } & \multicolumn{5}{|c|}{ Body weight (kg) } & \multirow[b]{2}{*}{150 days } \\
\hline & Birth & 30 days & 60 days & 90 days & 120 days & \\
\hline 2002 & $2.57 \pm 0.0354 \mathrm{a}$ & $4.83 \pm 1.096 \mathrm{~b}$ & $6.58 \pm 1.568 b$ & $8.03 \pm 1.968 c$ & $9.55 \pm 2.372 c$ & $12.17 \pm 2.944 \mathrm{c}$ \\
\hline 2003 & $2.34 \pm 0.403 b$ & $5.32 \pm 1.150 a$ & $7.34 \pm 1.514 \mathrm{a}$ & $9.14 \pm 1.88 b$ & $11.47 \pm 2.652 b$ & $13.68 \pm 2.87 b$ \\
\hline 2004 & $2.46 \pm 0.443 a b$ & $4.90 \pm 1.136 b$ & $7.33 \pm 1.765 a$ & $9.98 \pm 2.215 a$ & $13.08 \pm 3.152 \mathrm{a}$ & $15.01 \pm 4.21 \mathrm{a}$ \\
\hline 2005 & $2.41 \pm 0.340 \mathrm{ab}$ & $3.86 \pm 1.150 c$ & $5.60 \pm 1.033 c$ & $6.39 \pm 1.436 \mathrm{~d}$ & $9.10 \pm 1.616 \mathrm{c}$ & $9.96 \pm 2.604 d$ \\
\hline
\end{tabular}

a, b, c, d - Means with different superscripts within a column are different $(\mathrm{P}<0.05)$, by the pos hoc homogeneity Duncan test. 
days of age than those born in the hot wet season. The kids born in the hot wet season are lighter than those born in the rest of the year.

The month of birth has a significant effect on the body weights from birth to 150 days of age (Table 2), except for 30 days of age, which coincides with the results reported by Wenzhbong et al. (2005). Similar seasonal effects have been found by other authors (Nadarajah et al., 1995).

This could be explained by the same argument mentioned for the year effect. Al-Shorepy et al. (2002) indicated that the season of birth effect was not significant for birth weight. The effect of the month is caused by different feeding conditions generated in each season by irregular climatic conditions, especially in the arid areas (Gaddour et al., 2007). Pastoral resources change very much from one month to another, and for the same month from one year to another, thus directly affecting the intake of the kids and indirectly the milk production by the dams (Sajlu et al., 1999; Najari et al., 2007a). Zhang et al. (2008) reported that the weight variation for Boer goat in different years and seasons might be partly explained by differences in management and sample size.

The age of dam showed no effect $(\mathrm{P}>0.05)$ on the weights at birth and at the age of 30 days (Table 3 ). Different results were obtained by Wenzhbong et al. (2005) and Djemali et al. (1994).
The age of dam acts primarily by the variation of the mother dairy production according to the number of lactations (Najari, 2005). But this effect is probably more related to the lactation length than to the daily production; it is demonstrated by the no significance found for this effect on the weights at birth and at 30 days of age, just when all does are covering the demands of the kids. Djemali et al. (1994) has previously observed that growth traits increased with the age of dam up to 5 years of age, and they decreased in later ages. Another explanation of the mother age effect on the kids weights after 60 days is the high relation between milking ability and body size in this population, specially when lower body size is due to a praecox mating (Nadarajah et al., 1995).

Portolano et al. (2002) also reported that the age of dam had a significant effect on the pre and post-weaning growth period between 0 to 15 days of age and between 45 to 60 days of age, respectively, whereas it was not significant in the weaning period (between 30 and 45 days old). Kids born from older goats were heavier at birth but not in the case of goats above 8 to 10 years of age. Despite of this Al-Shorepy et al. (2002) did not find any significant effects of the age of dams at kidding for all traits.

The body weights from birth to the age of 150 days for males are all significantly heavier than those for females (Table 4), which are in agreement to the results reported by

Table 2 - Means of body weights at birth, 30, 60, 90, 120 and 150 days of age for Tunisian local kids according to the kidding month

\begin{tabular}{clllrrr}
\hline \multirow{2}{*}{ Factor } & \multicolumn{5}{c}{ Body weight $(\mathrm{kg})$} \\
\cline { 2 - 7 } & \multicolumn{1}{c}{ Birth } & 30 days & 60 days & 90 days & 120 days \\
\hline Months & & & & & \\
1 & $2.56 \pm 0.490 \mathrm{a}$ & $4.73 \pm 1.41 \mathrm{a}$ & $7.23 \pm 1.91 \mathrm{a}$ & $9.33 \pm 2.122 \mathrm{a}$ & $11.78 \pm 2.658 \mathrm{a}$ & $13.25 \pm 3.488 \mathrm{a}$ \\
2 & $2.52 \pm 0.239 \mathrm{a}$ & $4.89 \pm 1.15 \mathrm{a}$ & $6.81 \pm 1.39 \mathrm{a}$ & $8.02 \pm 1.637 \mathrm{~b}$ & $9.46 \pm 2.194 \mathrm{~b}$ & $13.44 \pm 3.315 \mathrm{a}$ \\
3 & $2.11 \pm 0.711 \mathrm{~b}$ & $4.24 \pm 1 \mathrm{a}$ & $6.07 \pm 0.9 \mathrm{~b}$ & $6.90 \pm 1.033 \mathrm{c}$ & $8.17 \pm 1.294 \mathrm{~b}$ & $9.45 \pm 1.622 \mathrm{~b}$ \\
12 & $2.43 \pm 0.4 \mathrm{ba}$ & $4.80 \pm 1.11 \mathrm{a}$ & $6.71 \pm 1.633 \mathrm{ba}$ & $8.45 \pm 2.397 \mathrm{ba}$ & $10.99 \pm 3.106 \mathrm{a}$ & $12.83 \pm 3.813 \mathrm{a}$ \\
\hline
\end{tabular}

a, b, c - Means with different superscripts within a column are different $(\mathrm{P}<0.05)$, by the pos hoc homogeneity Duncan test.

Table 3 - Body weights means at birth, 30, 60, 90, 120 and 150 days of age for Tunisian local kids according to the different age of dam

\begin{tabular}{|c|c|c|c|c|c|c|}
\hline \multirow{2}{*}{ Factor } & \multicolumn{6}{|c|}{ Body weight (kg) } \\
\hline & Birth & 30 days & 60 days & 90 days & 120 days & 150 days \\
\hline \multicolumn{7}{|c|}{$\begin{array}{l}\text { Age of dam } \\
\text { (years) }\end{array}$} \\
\hline 2 & $2.47 \pm 0.357 \mathrm{a}$ & $4.56 \pm 1.249 \mathrm{ba}$ & $6.32 \pm 1.399 \mathrm{ba}$ & $8.36 \pm 2.33 \mathrm{ba}$ & $10.97 \pm 3.07 \mathrm{a}$ & $12.39 \pm 3.785 \mathrm{a}$ \\
\hline 3 & $2.35 \pm 0.460 \mathrm{a}$ & $4.92 \pm 1.245 \mathrm{ba}$ & $6.67 \pm 1.666 \mathrm{ba}$ & $8.41 \pm 2.14 \mathrm{ba}$ & $10.75 \pm 3.215 a$ & $12.66 \pm 4.11 \mathrm{a}$ \\
\hline 4 & $2.43 \pm 0.323 a$ & $5.16 \pm 1.009 a$ & $6.98 \pm 1.546 \mathrm{ba}$ & $8.60 \pm 2.274 \mathrm{ba}$ & $10.76 \pm 3.024 a$ & $13.19 \pm 3.371 \mathrm{a}$ \\
\hline 5 & $2.50 \pm 0.366 \mathrm{a}$ & $4.81 \pm 1.044 \mathrm{ba}$ & $7.20 \pm 1.784 \mathrm{ba}$ & $8.84 \pm 2.344 \mathrm{ba}$ & $11.03 \pm 3.302 \mathrm{a}$ & $13.30 \pm 4.112 \mathrm{a}$ \\
\hline 6 & $2.50 \pm 0.398 a$ & $4.67 \pm 1.116 \mathrm{ba}$ & $6.65 \pm 1.728 \mathrm{ba}$ & $9.05 \pm 2.140 \mathrm{a}$ & $11.94 \pm 2.848 \mathrm{a}$ & $13.30 \pm 3.102 \mathrm{a}$ \\
\hline 7 & $2.51 \pm 0.278 a$ & $4.07 \pm 1.002 b$ & $6.14 \pm 1.231 \mathrm{~b}$ & $7.48 \pm 2.281 b$ & $10.34 \pm 1.734 a$ & $13.77 \pm 3.102 \mathrm{a}$ \\
\hline 8 & $2.23 \pm 0.417 \mathrm{a}$ & $4.05 \pm 1.765 b$ & $6.24 \pm 2.094 b$ & $7.56 \pm 3.522 b$ & $10.55 \pm 3.500 \mathrm{a}$ & $10.94 \pm 2.712 \mathrm{a}$ \\
\hline 9 & $2.56 \pm 0.364 \mathrm{a}$ & $5.13 \pm 1.351 \mathrm{a}$ & $7.46 \pm 1.776 a$ & $9.19 \pm 2.299 a$ & $11.22 \pm 2.610 \mathrm{a}$ & $13.11 \pm 3 \mathrm{a}$ \\
\hline 10 & $2.34 \pm 0.445 a$ & $4.62 \pm 1.150 \mathrm{ba}$ & $6.04 \pm 1.254 \mathrm{~b}$ & $7.62 \pm 2.145 b$ & $10.05 \pm 2.831 \mathrm{a}$ & $12.44 \pm 3.187 \mathrm{a}$ \\
\hline
\end{tabular}

a, b - Means with different superscripts within a column are different $(P<0.05)$, by the pos hoc homogeneity Duncan test. 
Table 4 - Body weights means at birth, 30, 60, 90, 120 and 150 days of age for Tunisian local kids according to both sexes and birth types

\begin{tabular}{|c|c|c|c|c|c|c|}
\hline \multirow{2}{*}{ Factor } & \multicolumn{5}{|c|}{ Body weight (kg) } & \multirow[b]{2}{*}{150 days } \\
\hline & Birth & 30 days & 60 days & 90 days & 120 days & \\
\hline \multicolumn{7}{|l|}{ Sex } \\
\hline Male & $2.57 \pm 0.451 \mathrm{a}$ & $4.80 \pm 1.164 \mathrm{a}$ & $6.99 \pm 1.871 \mathrm{a}$ & $8.90 \pm 2.463 a$ & $11.49 \pm 3.359 a$ & $13.53 \pm 4.067 \mathrm{a}$ \\
\hline Birth type & & & & & & \\
\hline single & $2.53 \pm 0.406 a$ & $5.05 \pm 1.174 a$ & $7.38 \pm 1.707 a$ & $9.22 \pm 2.395 a$ & $11.75 \pm 3.198 \mathrm{a}$ & $13.85 \pm 3.93 a$ \\
\hline twins & $2.35 \pm 0.398 b$ & $4.45 \pm 1.034 b$ & $6.08 \pm 2.281 b$ & $7.70 \pm 1.893 b$ & $9.22 \pm 2.421 b$ & $11.77 \pm 3.08 b$ \\
\hline
\end{tabular}

a, b - Means with different superscripts within a column are different $(\mathrm{P}<0.05)$, by the pos hoc homogeneity Duncan test.

other authors (Gebrelul et al., 1994; Ugur et al., 2004; Najari, 2005). However, Ndlovu \& Simela (1996) observed that the sex of kids did not affect body weights and growth rate from 90 to 180 days of age. Furthermore, the weight gap between males and females becomes larger as they become older, which is consistent with the reports by Hary \& Schwartz (2002). These growth advantages of male kids recorded in this study are comparable to those reported for other goat breeds (Husain et al., 1996; Al-Shorepy et al., 2002).

The superiority of the males on females may be explained by the precocity of the male. The sexual dimorphism in favour of males in body growth found in this paper is a common characteristic expressed in mammals, but in domesticated populations the level of dimorphism is closely related to the degree of selection developed on the population. A high sexual dimorphism as this one found in this study is common in the primitive unselected breeds. This dimorphism is present throughout the life of the animals, but it increases proportionally from birth to adulthood, when the weight is about $35 \mathrm{~kg}$ in the female and $55 \mathrm{~kg}$ in the male (Chriha \& Ghadri, 2001).

The effect of birth type on the body weight of kids at different ages was significant (Table 4). Single kids are always heavier than twins. Hary \& Schwartz (2002) reported that the single-born kids were found to be significantly heavier at all ages than twin-born kids. They also observed that the discrepancy in body weight of twins initially increased from $7 \%$ at birth to $22 \%$ at weaning. Portolano et al. (2002) showed that much of the variation in birth weight was associated to the type of birth, single birth was heavier than multiple born kids (Gebrelul et al., 1994). Alexandre et al. (1997) indicated that the difference between the single and twins could reach up to $15 \%$.

This variation can be partially explained by insufficient maternal production of milk to satisfy the requirements of more than one kid under hard conditions and forage scarcity. The disadvantage of the twins on the following weight growth may also result from weaker birth than the single (Sacker \& Trail, 1996; Gromela et al., 1998). Birth weight of kids is regarded as one of the most important contributory factors for survival and for improving growth performances (Husain et al., 1996). Zhang et al. (2008) reported that the growth advantage of single born at birth might result from less competition for nutrition supply from the dam in gestation period than the multiple birth ones.

Anyway, no differences between single and twin animals have been reported in adult weights. This can be explained by the compensatory growth in the older periods of growing.

\section{Conclusions}

Most of the non genetic effects tested in the present study are very important on body weights of kids during early age under Tunisian arid conditions, such as kidding year and month, sex, birth type and the age of dam. As this is one of the first studies on body weight of commercial kids developed in the North-African region, its findings can be used as a model to design regional policies on breeding, animal production and commercialization in this region.

\section{Acknowledgements}

The authors are grateful to the members of the Laboratoire d'Elevage et Faune Sauvage, Southern Tunisia, for their technical assistance.

\section{References}

ALEXANDRE, G.; AUMONT, G.; DESPOIS, P. et al. Productive performances of guadeloupean Creole goats during the suckling period. Small Ruminant Research, v.34, p.157-162, 1997.

AL-SHOREPY, S.A.; ALHADRAMI, G.A.; ABDULWAHA, K. Genetic and phenotypic parameters for early growth traits in Emirati goat. Small Ruminant Research, v.45, p.217-223, 2002.

BOCQUiER, F.; LEBOEUF, B.; ROUEL ET, J. et al. Nutrition effects and breeding mode upon young goat performances. INRA Productions Animales, v.11, p.311-320, 1998.

CHRIHA, A.; GHADRI, G. Caprine in the Arab world. 2.ed. Department of Livestock Production. Fateh University: Libby Conservation of Biodiversity and Environments in the Arab Countries, 2001. 478p. 
DGPDA. Government statistics of Tunisian gouvernement. Tunisia: Tunisian Agriculture Minister, 2005. 45p.

DJEMALI, M.; ALOULOU, R.; BEN SASSI, M. Adjustment factors and genetic and phenotypic parameters for growth traits of Barbarine lambs in Tunisia. Small Ruminant Research, v.13, p.41-47, 1994.

DE LANGE, C.F.M.; SZKOTNICKI, B.; MORPHY, J. et al. Establishing feed intake and growth curves for individual growing-finishing pig units. 17.ed. Community Center: Anual Centralia Swine research update, Kirkton-Woodham, 1998. 341p.

GADDOUR, A.; NAJARI S.; OUNI, M. Kid's growth of pure breeds and crossed caprine genotypes in the coastal oases of southern Tunisia. Research Journal of Agronomy, v.2, p.51-58, 2007.

GBANGBOCHE, A.B.; ADAMOU-NDIAYE, M.; YOUSSAO, A.K.I. et al. Non-genetic factors affecting the reproduction performance lamb growth and productivity indices of Djallonke sheep. Small Ruminant Research, v.64, p.133-142, 2006

GEBRELUL, S.; LEON, S.; SARTIN, III. et al. Genetic and non-genetic effects on the growth and mortality of Alpine, Nubian and crossbred kids. Small Ruminant Research, v.13, p.169-176, 1994.

GENANDOY, H.; SAHLU, T.; DAVIS, J. et al. Effects of different feeding methods on growth and harvest traits of young Alpine kids. Technical note. Small Ruminant Research, v.44, p.81-87, 2002.

GROMELA, E.H.; LEDIN, I.; UDÉN, P. On-farm performance of dual purpose goats and farmers' attitudes towards introduction of goats in HADO Areas of Kondoa. Africa Integrated Farming in Human Development. In: WOMEN IN AGRICULTURE AND MODERN COMMUNICATION TECHNOLOGY, Tune landboskole, 1998, Danemark. Proceedings... Danemark: 1998. (CD-ROM).

HARY, I.; SCHWARTZ, H.J. Effects of seasonal breeding on productive performance of pastoral goat herds in northern Kenya: a longitudinal analysis of growth in kids and body weight development of does. Journal of Arid Environments, v.50, p.641-664, 2002.

HUSAIN. S.S.; HORST, P.; ISLAM, A.B.M.M. Study on the growth performance of Black Bengal goats in different periods. Small Ruminant Research, v.21, p.165-171, 1996.

KNNAN, G.; GADIYARAM, K.M.; GALIPALLI, S. et al. Meat quality in goats as influenced by dietary protein and energy levels, and postmortem aging. Small Ruminant Research, v.61, p.45-52, 2006.

KOSGEY, I.S.; GADIYARAM, K.M.; GALIPALLI, S. et al. Successes and failures of small ruminant breeding programmes in the tropics: a review. Small Ruminant Research, v.61, p.13-28, 2006.

LE GAL PLANCHENAULT, O. Use of the caprine races in the hot zones. Constraints and interests. Toulouse: UCARDEC CTA, 1993. 26p.

MAHJOUB, O.; LU, C.D.; HAMEED, M.S. et al. Performance of Omani goats fed diets containing various metabolisable energy densities. Small Ruminant Research, v.58, p.175-180, 2005.

MORAND-FEHR, P. Growth. In: GALL, C. (Ed.) Goat production. London: Academic Press, 1981. p.253-283.

NADARAJAH, K.; BURNSIDE, E.B.; KENNEDY, D. Estimation of phenotypic and genetic parameters for growth of goats enroled in the Ontario Goat Herd Improvement Program (GHIP). Ontario: Centre for Genetic Improvement of Livestock 1995. 2p. (Annual Report).

NAJARI, S. Zootechnical and genetic characterization of a caprine population. Case of the local caprine population of the Tunisian arid areas. 214f. 2005. Thesis (Ph D. in Agronomy) - Institut National Agronomique de Tunis, Tunisia.

NAJARI, S.; BEN HAMOUDA, M.; KHALDI, G. Expression of the kid's genotypes in arid regions conditions. In: WORLD CONGRESS ON GENETICS APPLIED TO LIVESTOCK PRODUCTION, 7., 2002, Montpellier. Proceedings... Montpellier: 2002. p.401-404.

NAJARI, S.; GADDOUR, A.; BEN HAMOUDA, M. et al. Growth model adjustment of local goat population under pastoral conditions in tunisian arid zone. Journal of Agronomy, v.6, n.1, p.61-67, 2007a.

NAJARI, S.; GADDOUR, A.; OUNI, M. et al. Indigenous kids weight variation with respect to non genetic factors under pastoral mode in Tunisian Arid Region. Journal of Animal and Veterinary Advances, v.6, n.3, p.441-450, 2007b.

NDLOVU, L.R.; SIMELA, L. Effect of season of birth and sex of kid on the production of live weaned single born kids in smallholder East African goat flocks in North East Zimbabwe. Small Ruminant Research, v.22, p.l-6, 1996.

OLIVEIRA, J.B.; PIRES, A.J.V.; CARVALHO, G.G.P. et al. Subprodutos industriais na ensilagem de capim-elefante para cabras leiteiras: consumo, digestibilidade de nutrientes e produção de leite1. Revista Brasileira de Zootecnia, v.39, n.2, p.411-418, 2010.

OLTENACU, E.A.B. Using math to see how well your goat is growing. New York state $4 \mathrm{H}$ meat goat project fact sheet 16 . Ithaca: Cornell University, 1999.

OUNI, M. Morphometric characterization of the goat genetic resources in the Tunisian arid zones. 100f. 2006. Thesis doctorate, Faculty of Science of Tunis, Tunizia.

OUNI, M.; NAJARI, S.; GADDOUR, A. et al. Early growth of morphometric traits of local goat population in Tunisian arid zone. Journal of Biological Sciences, v.7, n.7, p.1194-1200, 2007.

OUNI, M.; NAJARI, S.; GADDOUR, A. et al. Morphostructural growth according to the sex and birth mode and relationship between Body size and body weight of the local kids' at the first five month of age inTunisian arid area. Research Journal of Biological Sciences, v.3, n.1, p.120-127, 2008a.

OUNI, M.; NAJARI, S.; GADDOUR, A. et al. Some non genetic factors effects on morphostructural growth of local kids in Tunisian arid area. International Journal of Zoological Research, v.4, n.1, p.12-20, 2008b

OULED BELGACEM, A. Ecological statute, biological performance and aptitude of the reinstalment of stipa lagascae $\mathrm{R}$ and $\mathrm{SCH}$ in the degraded ecosystems of the Tunisian arid mediums. 147f. 2006. Thesis (PhD in Agronomy) - Faculty of Science of Sfax, Tunez.

PARIACOTE, F. Productivity of goat native, alpine and nubian breeds and their crosses in Venezuela. Archivos de Zootecnia, n.41, p.555-562, 2003.

PORTOLANO, B.; TODARO, M.; FINOCCHIARO, R. et al. Estimation of the genetic and phenotypic variance of several growth traits of the Sicilian Girgentana goat. Small Ruminant Research, n.45, p.247-253, 2002.

SACKER, G.D.; TRAIL, J.C.M. Production characteristics of a herd of E. African Mubende goats. Tropical Agriculture, v.43, p.4351, 1996.

SAJLU, T.; HART, S.P.; GOETSCH, A.L. Effects of level of feed intake on body weight, body components, and mohair growth in Angora goats during realimentation. Small Ruminant Research, v.33, p.251-259, 1999.

STATISTICAL ANALYSIS SYSTEM - SAS. Systems for Microsoft Windows, Release 6.12. Cary: SAS Institute, 1999. 956p.

UGUR, F.; SAVAS, T.; DOSAY, M. et al. Growth and behavioural traits of Turkish Saanen kids weaned at 45 and 60 days. Smal Ruminant Research, v.52, p.179-184, 2004.

WALKDEN-BROWN, S.W.; NORTON, B.W.; RESTALL B.J. Seasonal variation in voluntary feed intake in cashmere bucks fed ad libitum diets of low or high quality. Australian Journal of Agricultural Research, v.45, p.355-366, 1994.

WENZHONG, L.; YUAN, Z.; ZHONGXIAO, Z. Adjustement for non-genetic effects on body weight and size in Angora goats. Small Ruminant Research, v.59, p.25-31, 2005.

ZHANG, C.; YANG L.; SHEN, Z. Variance components and genetic parameters for weight and size at birth in the Boer goat. Livestock Science, v.115, p.73-79, 2008.

ZHANG, C.Y.; SHEN, Z.; ZHOU, Z.Q. et al. Studies on the growth and developmental rules of young Boer goat. Journal Huazhong Agricultural University, v.12, p.640-644, 2006. 